\title{
ALTERATIONS IN P53 GENE, TESTICULAR AND HEPATIC TISSUES OF ALBINO RATS DUE TO PROFENOFOS ADMINISTRATION: A POSSIBLE PROTECTIVE EFFECT OF VITAMIN C. \\ Dessouki, Amina'; Abeer Hassan ${ }^{2}$; Saadia. Ali $^{3}$ and Naglaa Loutfy ${ }^{4}$ Department of Pathology ${ }^{1}$, Biochemistry ${ }^{2}$ and Physiology ${ }^{3}$, Faculty of Veterinary Medicine, Suez Canal University, Ismailia, 41522 Egypt. \\ ${ }^{4}$ Department of Plant Protection, Faculty of Agriculture, Suez Canal University, Ismailia, 41522 Egypt.
}

\begin{abstract}
The effects of profenofos on rat testis and liver was evaluated when applied for 10 weeks, either alone or mixed with vitamin C. Sperm counts, motility, morphology, reduced glutathione, catalase, superoxide dismutase, malodialdehyde, testosterone level, RT-PCR SSCP of gene P53 were studies. Significant decrease in sperm motility and survival were observed in treated rats. Serum testosterone decreased after exposure for 5 and 10 weeks. MDA content in serum, liver and testis showed significant increase. The activity of hepatic SOD increased, while CAT activity was not changed after 5 weeks exposure. After 10 weeks exposure, the activity of SOD and CAT in both liver and testis, were lower than the control group. At the end of the two exposure periods, GSH levels in both tissues were significantly higher in profenofos treated groups compared to control group. Results of 10 weeks exposure using RT- PCR SSCP analysis suggested profenofos induction of genotoxicity.

Keywords: Profenofos; rats; p53 gene; SSCP; SOD; CAT, GSH, histopathology; spermogram;
\end{abstract}

\section{INTRODUCTION}

The extensive use of organophosphorus pesticides in pest control has caused severe environmental pollution, with undesirable impacts on man and his environment. lack of regulating laws, and necessary enforcements are major reasons for pesticides pollution in developing countries. The majority of the population in these countries is exposed to pesticides via contaminated food, drinking water, or through the application of household insecticides. Exposure to low levels of organophosphates is known to produce a variety of biochemical changes, some of which may be responsible for the adverse biological effects reported in humans and experimental animals (Sultatos, 1994).

Many organophosphates exert their toxic effects via oxidative stress mechanisms. This in turn would lead to the generation of reactive oxygen species (ROS) and significant alterations in antioxidants or ROS/RNS scavenging enzyme system (Sharma et al., 2005; Beuret et al., 2005; Astiz et al., 2009a; Kalender et al., 2010). Organophosphates are also known to induce toxicity in mammals by inhibiting acetylcholinesterase (AChE), and the accumulation of acetylcholine and the subsequent activation of cholinergic muscarinic and nicotinic receptors (Buyukokuroğlu et al., 2008). Profenofos is also considered a male reproductive toxicant (Moustafa et al., 2007). 
Dessouki, Amina et al.

Profenofos is a broad spectrum insecticide widely used in agricultural and household applications in many countries including Egypt. Greish et al. (2011) reported that profenofos was the most commonly organophosphate used in Egypt, with detectable residue level in tomato, cucumber, pepper and strawberry samples collected from local markets.

Gene p53 is a central component of a system that eliminates pathologically damaged cells from an organism. The task of p53 is to control the integrity and correctness of all processes in each individual cell and in the organism as a whole. Moreover, P53 gene is involved in the regulation of the cellular stress response by controlling the induction of apoptosis or growth arrest. In this study, the p53 was used as a biomarker of the stressful conditions of the cell that reflects DNA damage that may lead to tumors.

Several experimental studies have shown that antioxidant vitamins could ameliorate pesticide toxicity (Altuntas et al., 2002; Uzunhisarcikli et al., 2007). Antioxidant vitamins have a number of biological activities, including immunity stimulation, beside altering the metabolic activities of carcinogens. These vitamins can also prevent genetic changes by inhibiting the DNA damage induced by reactive oxygen metabolites (Verma et al., 2007). Vitamin C (ascorbic acid) is a well-known low molecular weight antioxidant that protects the cellular compartment from water-soluble oxygen nitrogen radicals (Jurczuk et al., 2007). It efficiently inhibits in vitro lipid peroxidation due to a combination of direct radical interception and interaction with átocopherol as a co-antioxidant (Verma et al., 2007). Vitamin C can also restore the antioxidant abilities of vitamin $E$, suggesting that one of its major functions is to recycle the tocopheroxyl radical (Serbecic and Beutelspacher, 2005).

The present study was conducted to evaluate the biochemical and histopathological effects of profenofos-induced oxidative damage on rat testis and liver as well as the effects on P53 gene in liver tissues. The study also meant to evaluate the possible protection that ascorbic acid might have against pesticides effects.

\section{MATERIALS AND METHODS}

\section{Experimental animals}

Sexually mature male Albino rats (weighing approximately $150 \pm 10$ g) obtained from the General Organization of Serum and Vaccine, Helwan Farm, Egypt were used throughout. Rats were housed in metal cages, fed on a standard diet and water ad libitum, maintained under a $12 \mathrm{~h}$ light/dark cycle, at a laboratory temperature of $23 \pm 3 \mathrm{C}$. Rats were acclimatized for two weeks before starting the experiments. All rats were handled in accordance with the standard guide for the care and use of laboratory animals.

\section{Chemicals}

Profenofos (Selecron EC $72 \%$ ) was obtained from the Central Agricultural Insecticides Laboratory, Egypt. Vitamin C (L-ascorbic acid) was supplied by Loba Chemie, India. (Available at: www.lobachemie.com 


\section{Experimental design}

The rats were randomly divided into four groups each containing six animals. The first group (G I) was given distilled water and designated as control. The second group (G II) was treated with profenofos, at a dose of $17.8 \mathrm{mg} / \mathrm{kg}\left(1 / 20\right.$ of $L D_{50}$ based on the work of (Moustafa et al., 2007). The third group (G III) was given a combination of profenofos $(17.8 \mathrm{mg} / \mathrm{kg} \mathrm{B.W})$ and ascorbic acid (100 mg/kg B.W) while Group (VI) was given ascorbic acid only $(100 \mathrm{mg} / \mathrm{kg} \mathrm{B.W})$. Each treatment was dissolved in $0.5 \mathrm{ml}$ distilled water then given orally using stomach tube. Solutions were prepared just prior to application and were administered in the morning to non-fasting rats. Treatments were repeated twice weekly for ten weeks. Body weight was monitored weekly and the doses were adjusted accordingly.

\section{Sampling}

Blood and tissue samples were collected 5 and 10 weeks after exposure. Blood samples were taken from medial canthus of the eye by cardiac puncture, using a syringe, transferred into micro test tubes and allowed to clot, then centrifuged at $3000 \mathrm{rpm}$ for $15 \mathrm{~min}$ and serum was separated and stored at $-20^{\circ} \mathrm{C}$ until both testosterone and malodialdehyde (MDA) were determined. Testis and liver tissues were washed in saline then kept at $-20^{\circ} \mathrm{C}$ until MDA, catalase (CAT), reduced glutathione (GSH) and superoxide dismutase (SOD) were determined. In addition, at the end of $10^{\text {th }}$ week of profenofos exposure, RT-PCR SSCP of gene P53 of treated liver and testis were determined. In this respect, parts of liver and testis were snapped in liquid nitrogen at $-196^{\circ} \mathrm{C}$, then kept at $-80^{\circ} \mathrm{C}$ and sent for the by RT-PCR of p53 analysis (Cairo University).

\section{Biochemical Determination}

Serum total testosterone was determined according to Jaffe and Beherman (1974). MDA was determined in serum, testis and liver tissues according to Ohkawa et al. (1979). Activities of CAT and SOD and reduced GSH were determined in testis and liver tissue according to Aebi (1974), Misera and Fridovich (1972) and Anderson (1985), respectively. Tissue samples, used to determine the previous parameters were prepared by homogenizing $1 \mathrm{~g}$ of tissue in $10 \mathrm{ml}$ of buffer according to the kit instructions for each parameter.

\section{Determination of RT-PCR SSCP}

Liver tissues of 10 weeks exposure were used to determine Reverse Transcription-Polymerase Chain Reaction single stranded conformational polymorphism (RT-PCR SSCP) of P53 gene. RT-PCR was performed according to Bustin et al. (2005) as the following:

a-RNA extraction

b-RT-PCR

c-RT-PCR sscp

Total RNA was isolated from liver tissue with Trizol reagent (GibcoBRL, Grand Island, NY) according to the manufacturer's instructions. The first strand of complementary DNA was synthesized by reverse transcription (RT) of $2 \mathrm{mg}$ of total RNA with oligo-dT primer and Superscript II reverse transcriptase (Gibco-BRL). After the RT reaction, $10 \mu \mathrm{l}$ of the incubation 


\section{Dessouki, Amina et al.}

mixture was used as the template for the subsequent polymerase PCR amplification. The forward $(F)$ and reverse strand $(R)$ PCR primer were: p53 (F), 5'-GTT TCC GTC TGG GCT TCT-3'; p53(R), 5'-ACC TCA GGC GGC TCA TAG-3'; PCR products were carried out in a condition of, 3 min at $94^{\circ} \mathrm{C}$ for initial denaturing, followed by 35 cycles of amplification $\left(94^{\circ} \mathrm{C}\right.$ for $30 \mathrm{sec}$, $55^{\circ} \mathrm{C}$ for $30 \mathrm{sec}$, and $72^{\circ} \mathrm{C}$ for $30 \mathrm{sec}$ ) using Go Taq (Promega). Amplified products were visualized on $2 \%$ agarose gel with ethidium bromide. For SSCP, ten $\mu \mathrm{l}$ of RT-PCR products were aspirated, equal volumes of deionized formamide and $4 \mu \mathrm{l}$ of DNA loading buffer $(0.25 \%$ bromophenol blue, $0.25 \%$ xylene cyanol FF, 30\% glycerol) were added. .The mixture was boiled for $5 \mathrm{~min}$. and then chilled on ice for $3 \mathrm{~min}$. Samples were run in $8 \%$ non-denaturing polyacrylamide gel at $80 \mathrm{~V}$ for $5 \mathrm{hrs}$. The gel was taken off from the electrophoresis apparatus and submerged in ethidium bromide solution for $3 \mathrm{~min}$. then viewed by UV and photographed.

\section{Histopathological studies}

Specimens of liver and testis were dissected and fixed in 10\% neutral buffered formalin. Following fixation the specimens were carefully washed in running tap water, dehydrated in an ascending series of alcohol, cleared in xylene and then embedded in paraffin wax. Sections of $5 \mu$ thickness each were cut and stained with haematoxylin and eosin according to a method adopted by Drury and Wallington (1980). Sections were then investigated under light microscope.

\section{Statistical analysis}

The data obtained from the biochemical analysis of different rat groups are represented as Mean \pm Standard error (mean \pm SE). The significance of the difference between the groups was calculated by one-way analysis of variance (ANOVA) using the SPSS-PC computer software package version 10 .

\section{RESULTS AND DISCUSSION}

\section{Evaluation of epididymal semen picture}

The effect of oral administration of profenofos on sperm percent motility, percent survival and abnormalities at the end of the $5^{\text {th }}$ and 10th week is shown in Table 1. Rats treated with profenofos exhibited a significant decrease in sperm motility and viability $(p<0.05)$. Primary and total sperm percent abnormalities have significantly $(p<0.05)$ increased between the 5 and 10 weeks exposure in profenofos-treated group compared to the control. At the end of the $5^{\text {th }}$ and $10^{\text {th }}$ week, the vitamin-treated and control rats have shown no significant difference in their rates of abnormal sperm morphology but the profenofos-vitamin $\mathrm{C}$ treated rats and profenofos-treated rats had significantly higher abnormal sperm morphology rates than the control (Table 1).

Our results are in agreement with Uzunhisarcikli et al. (2007) and Uzun et al. (2009). They reported a significant decrease in sperm motility and viability and an increase in abnormal sperm morphology in rats exposed to the two organophosphates malathion and methyl parathion. 
J. Plant Prot. and Path., Mansoura Univ., Vol. 3 (5), May, 2012 
Dessouki, Amina et al.

2

420 
They attributed these effects, to the ability of these compounds to cross the blood-testis barrier (Uzunhisarcikli et al., 2007), after which they induce oxidative stress and lipid peroxidation that damages the biological membranes in the testis. This in turn may cause the degeneration of the spermatogenic and Leydig cells, which disrupt spermatogenesis and reduces sperm counts. The sperms themselves may also be damaged by the oxidative effects of these organophosphates, which affect the activities of mitochondrial enzymes and the structure of the microtubules in the sperm, hence reducing their motility. The ROS may also contribute to infertility caused by defective sperm function as previously reported (Latchoumycandane et al., 2002).

Sarabia et al.(2009) suggested that DNA damage is probably another mode of action of organophosphates effect on male reproductive function. Since sperm morphology is controlled by various autosomal and Y-specific genes (Forejt, 1976; Krazanowska, 1976), DNA damage may also reduce sperm motility. This assumption is supported by our histopathological analysis of the profenofos-treated rats that revealed, oedema and necrosis in the seminiferous tubules and interstitial tissue of rat testis.

In the present study, combination of profenofos and vitamin $\mathrm{C}$ improved semen quality.Treatment with vitamin $C$ alone improved spermiogram profile. Likewise, Uzunhisarcikli et al. (2007) and Uzun et al. (2009) have reported that administration of vitamins $C$ and $E$ improves sperm counts, motility, and morphology.

Ascorbic acid functions as an important free radical scavenger that traps free radicals in the aqueous phase thus protecting biomembrane from oxidative damage (Altuntas et al., 2002). In addition, ascorbic acid has long been established as an agent of crucial role in the differentiation process of the spermatogonial cells to sperms (Gangadharan et al., 2001 and Sonmez et al., 2005).

\section{Effects on biochemical parameters}

Table (2) presents the effect of profenofos and/or ascorbic acid on serum testosterone and MDA levels in different tissues after exposure intervals of 5 and 10 weeks.

Compared to the control group, serum testosterone level decreased significantly $(\mathrm{P}<0.05)$ after the exposure either to profenofos or profenofos and ascorbic acid combination for 5 and 10 weeks (Table 2). Testosterone level meanwhile has decreased significantly in profenofos treated rats. These results are in agreement with some previous research suggesting that pesticides, especially some organophosphates are "hormonal disruptors" of mammals (Saradha and Mathur 2006; Astiz et al., 2009b). The pathological change in the Leydig cells in the interstitial tissues observed in the present study has been suggested as a reason for decreasing plasma testosterone level by Uzun et al. (2009).

Compared to the control group, MDA content in profenofos - vitamin $C$ treated serum, testis and liver tissues have significantly increased $(\mathrm{P}<0.05)$ after 5 and 10 weeks exposure, indicating a marked lipid peroxidation and damage of cell membranes due to oxidative stress. 


\section{Dessouki, Amina et al.}

Meanwhile, in case of profenofos - vitamin $C$ treated group exposed for 5 and 10 weeks, MDA content in serum and testis showed no difference with the control group. (Table 2). This result shows that vitamin $\mathrm{C}$ is playing a role in reducing the toxicity of profenofos to rats. However this is not the case in liver samples.

Polyunsaturated fatty acids are especially susceptible to peroxidation. This process produces a relatively unstable fatty acid hydroperoxides, then converted by consecutive scission, rearrangements, and oxidation to a more stable carbonyls like MDA. In addition to membrane effects, LPOs can damage DNA bases (primarily guanine via lipid peroxyls or alcoxyl radicals) as well as generate strand breaks and cross-linking through covalent binding to MDA (Sikka et al., 1995).

Results reported in this study for MDA content are in agreement with previous findings demonstrating the deleterious effects to lipids and proteins caused by pesticide-induced oxidative stress (Saradha and Mathur, 2006a; Acharya et al., 2008; Astiz et al., 2009b).

The level of antioxidant enzymes SOD and CAT and the water soluble antioxidant GSH, were measured in liver and testis of rats exposed to profenofos and/or ascorbic acid for 5 and 10 weeks (Table 3). After 5 weeks of exposure to profenofos, the activity of hepatic SOD increased, while CAT activity was not changed compared to control group. Meanwhile, after 10 weeks of exposure to profenofos the activity of SOD and CAT in both liver and testis, were lower than that of the control group.

After 5 weeks exposure to profenofos, the activity of SOD was restored to almost normal values upon treatment with vitamin $C$ in both tissues. But with the prolonged exposure period of 10 weeks, the enzyme activity was partially restored in liver only in profenofos - vitamin-treated group. However, vitamin C succeeded to ameliorate the activity of CAT completely in both tissues.

In view of our findings, a great alteration of redox status became evident in animals exposed to profenofos, indicating some physiological and histopathological changes in affected tissues. However, oxidative damage induced by ROS/RNS is directly involved in male infertility. Excessive ROS production may result in impaired steroidogenesis and spermatogenesis by several mechanisms, including DNA damage, lipid peroxidation and protein oxidation (Prahalathan et al., 2006).

In healthy aerobic organisms, the production of ROS and RNS is continuously balanced by an antioxidant defense system. It is well known that mammalian cells have a comprehensive set of antioxidant defense mechanisms to prevent free radical formation and also to limit their damaging effects (De Zwart et al., 1999). Within the first line of neutralizing agents, there are key enzymatic components such as SOD, which catalyzes the dismutation of $\mathrm{O}_{2-}$ to $\mathrm{H}_{2} \mathrm{O}_{2}$, and CAT, that promotes the direct decomposition of $\mathrm{H}_{2} \mathrm{O}_{2}$ to $\mathrm{O}_{2}$. Another line of defense is the so-called low-molecular-mass agents which scavenge ROS and RNS (glutathione and $\alpha$-tocopherol as the main protective agents for the water- and lipid-soluble cell components, respectively) (Buettner 1993). 
J. Plant Prot. and Path., Mansoura Univ., Vol. 3 (5), May, 2012 
Dessouki, Amina et al.

When these defensive mechanisms are insufficient, oxidative stress (OS) becomes evident (Cadenas and Packer 2002; Astiz et al., 2009b).

In the present study, the activity of hepatic SOD increased with profenofos treatment in comparison to the control group at the end of the 5th week. These findings are similar to those of Rai et al. (2009) who reported an elevation in the activity of SOD in carbofuran, an oxime carbamate insecticide -treated rat erythrocytes. They suggested that the activation is a compensatory mechanism after pesticide exposure, leading to reduction in the accumulation of excess superoxide anions in the body. The extent of its influence is correlated with the magnitude of ROS generation, and hence on the exposure to stressor (Prakasam et al., 2001).

After 10 weeks of exposure, the activity of SOD and CAT in both liver and testis were lower in profenofos treated group compared to control group. Similarly, Astiz et al. (2009a) observed that CAT activity in liver, brain and kidney of rates treated with three different types of pesticides was significantly reduced.

SOD is considered the most important antioxidant activity in spermatozoa with a key physiological role in epididymal sperm capacitation (Astiz et al. 2009b). Hence, lipid peroxidation of sperm membrane is considered to be the key mechanism of ROS-induced sperm damage.

CAT is inhibited by $\mathrm{O}^{2-}$ and ONOO-which affect the heme group (Franceschutti et al., 1996) located in the active site of the enzyme. This could be the reason why its activity was diminished under oxidative stress (Astiz et al., 2009a). Moreover, Patel et al., (2006) demonstrated that an increased MDA concentration attenuated the activity of enzymes involved in the detoxification of hydrogen peroxide, hydroxyl, and superoxide radicals. This also might explain SOD depletion reported in this study. At the end of treatment periods, GSH levels in both liver and testis tissues were significantly higher in profenofos treated group compared to control group. Vitamin C had partially restored GSH level in testis exposed for 10 weeks.

Reduced glutathione has multiple biological functions including acting as an enzyme cofactor, prevention of protein thiol oxidation, xenobiotic detoxifier, and as a scavenger of free radicals $(\mathrm{OH} \cdot, \mathrm{HOCl}, \mathrm{ONOO}-, \mathrm{RO} \cdot$, $\mathrm{ROO}^{-}$, and $\mathrm{O}^{2-}$ ) (Halliwell and Gutteridge, 1999). In the present study, the observed increase in reduced glutathione levels may be due to a compensatory mechanism evoked by the oxidative stress caused by profenofos. This explanation is in agreement with previous suggestions made by other authors (Sharma et al., 2005, Astiz et al., 2009a), and it may be the consequence of an induction of liver $\gamma$-glutamyl-cysteine synthetase, the enzyme that controls the biosynthesis of glutathione and the GSH exportation to plasma (Dringen, 2005). Astiz et al. (2009a) added that hepatocytes are able to increase glutathione biosynthesis and also reduce oxidized glutathione. Beside, Glutathione reductase activity has increased in testis treated with 2 different types of organophosphorus pesticides. This enzyme activity is necessary to regenerate GSH levels (Astiz et al., 2009b).

Antioxidant vitamins have a number of biological activities, including immunity stimulation and altering the metabolic activities of carcinogens. 
These vitamins can also prevent genetic changes by inhibiting the DNA damage induced by reactive oxygen metabolites (Verma et al., 2007 and Kalender et al., 2010). Vitamin C, a low molecular weight antioxidant, defends the cellular compartment against water-soluble oxygen nitrogen radicals (Jurczuk et al., 2007). It can also restore the antioxidant abilities of vitamin E, suggesting that one of its major functions is to recycle the tocopheroxyl radical (Serbecic and Beutelspacher, 2005).

\section{Alteration in RT- PCR of p53}

Results of RT- PCR of p53 gene of rats liver treated with profenofos alone or with ascorbic acid as compared to untreated or antioxidant-treated control are presented in Figure 1. Common amplified product of length170 bp P53 gene was expressed in all SSCP analysis (Figure 2), fragment different banding patterns.

Results of RT-PCR of P53 gene showed a single specific amplified product of $170 \mathrm{bp}$ long when total RNA from liver of rats treated with profenofos, either alone or in combination with antioxidant, and untreated or antioxidant-treated control, was used. This result may suggest that p53 gene was expressed, and this expression was confirmed at only the transcriptional level. Additionally, differential gene expression among the experimental groups of rats could not be deduced from such results. The abnormal band pattern observed upon conducting the RT-PCR SSCP analysis of P53 gene of liver of only profenofos-treated rats as compared to those of other treatments, including the control, may, however, suggest an induction of genotoxicity.

SSCP analysis detects structural variations in single stranded DNA of the same size due to the formation of sequence dependent intrastrand secondary structure (Orita et al., 1989). Hence, the abnormal band pattern observed upon conducting the RT-PCR SSCP analysis of P53 gene in liver of profenofos-treated rats may reflect a profenofos-induced mutation. It is very well established (Sheffield et al., 1993) that the single stranded DNAs differing in a single nucleotide will acquire different conformations that have different mobilities on a polyacrylamide gel. The absence of such abnormal band pattern from the lane corresponding to the liver of rats treated with combination of profenofos and antioxidants is likely to be due to the protective effect of antioxidant from the profenofos-induced DNA damage.

\section{Histopathological changes results}

Light microscopic analyses revealed that seminefrous tubules of testis of control group showed normal cell association, lined by a stratified epithelium of spermatogenic cells and sertoli cells. It also revealed the different stages of spermatogenesis, primary and secondary spermatocytes with formation of primary and late spermatides (Fig 3-a\&b).

Some histopathological changes were shown in semineferous tubules of profenofos treated group, with sloughing and disrupted cell arrangement. It was also indicated that after 5-weeks of exposure to profenofos some tubules were lined with moderate to few number of spermatogenic cells, while large number of spermatides exhibited degeneration and necrosis (Fig.3-c). 


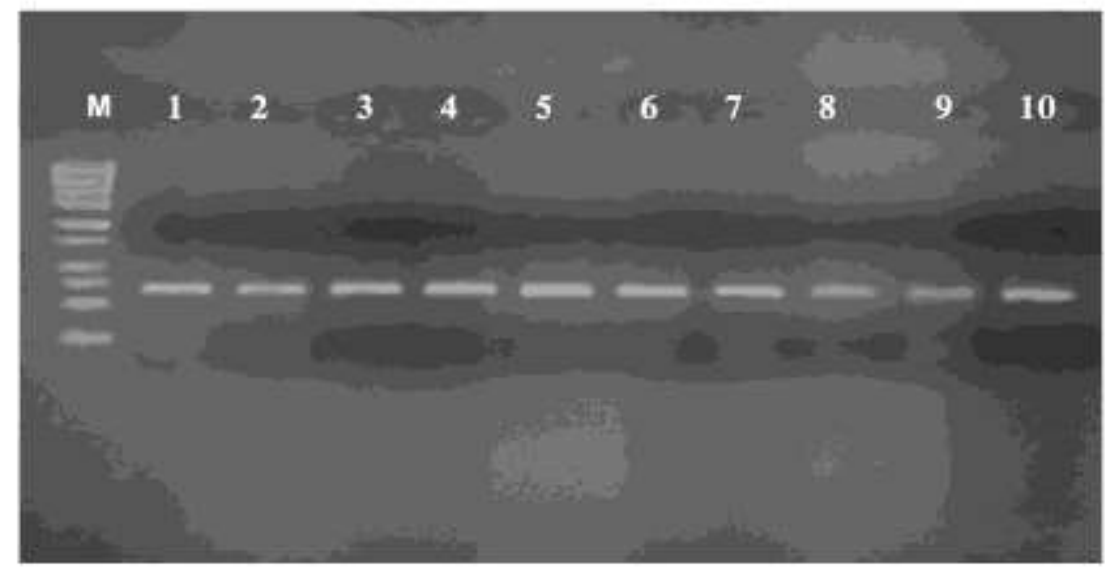

Figure 1: Agarose gel electrophoresis of RT- PCR products of p53 exon7. Lanes M: 250 bp DNA ladder,the figure showing expression of p53 gene in all groups. 1-2: control; 3-4: antioxidant (ascorbic acid); 5-7:profenofos and 8-10: profenofos plus antioxidant

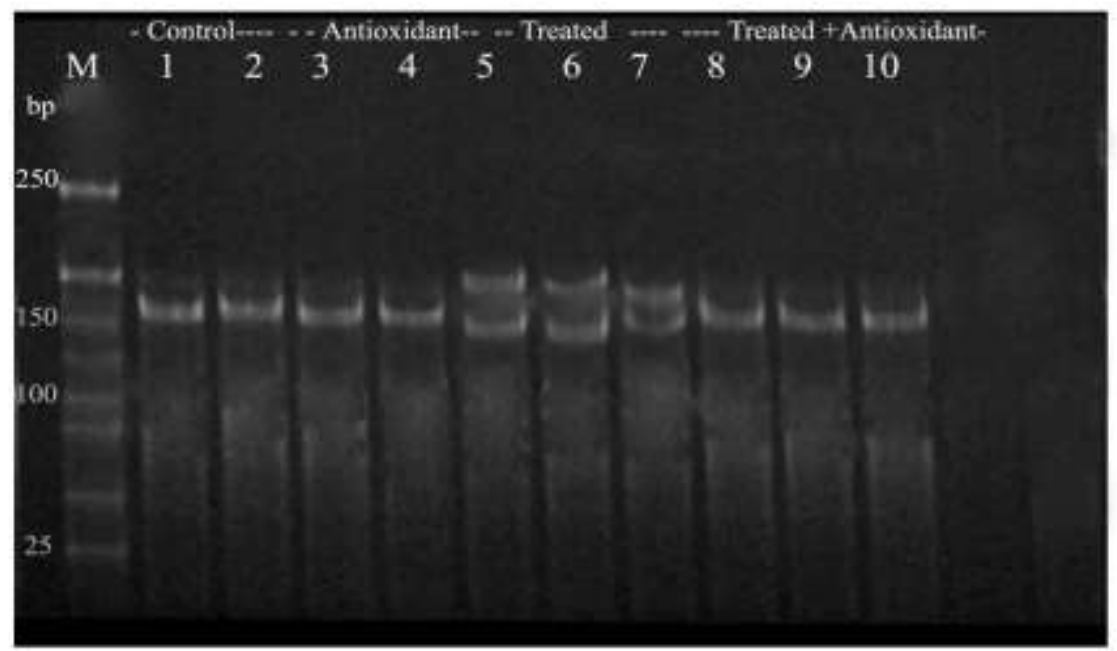

Figure 2: Polyacrylamide gel of RT-PCR SSCP of p53 gene in liver cells. M- 170 bp DNA ladder. 1-2: control; 3-4: antioxidant (ascorbic acid); 5-7: profenofos alone and 8-10: profenofos plus antioxidant. The shifted abnormal bands are shown in the liver after treatment with profenofos 
After 10-weeks of profenofos exposure, the interstitial space was enlarged due to edema, congestion of blood vessels and tubular atrophy of the semineferous tubules, while some sections had no spermatozoa (Fig.3-d \& Fig. 4-a). Edema and hemorrhages were also observed in the interstitial tissue. Most of the tubules showed thickening and hyalinization of their basement membranes, hyperplasia of sertoli cells lined with few number of spermatogenic cells characterized by signs of degeneration, vacuolization and necrotic changes (Fig. 4-b ).

Ferah (2007) observed testicular damage characterized by moderate to severe seminiferous tubule degeneration as sloughing, atrophy, germ cell degeneration and partial arrest of spermatogenesis due to dimethoate, another organophosphate toxicity.After 5 weeks of exposure to profenofos combined with ascorbic acid, few number of testicular seminefrous tubules showed mild sloughing of germ cells in their tubular lumen, and interstitial edema with presence of mature spermatozoa (Fig.4-C). While after 10 weeks of exposure, testis exhibited fairly normal spermatogenesis with formation of normal spermatides (Fig.4- d). Fatma et al. (2009) observed that vitamins C and $\mathrm{E}$ ameliorate malathion testicular toxicity but are not completely protective. The present results are in agreement with the results observed by Uzunhisarcikli et al. (2007) who observed that exposure to methyl parathion for 4 and 7 weeks, caused necrosis and edema in the somniferous tubules and interstitial tissues. They concluded that vitamins $C$ and $E$ reduces methyl parathion testicular toxicity, but would not provide complete protection.

Liver of control rats showed normal polyhedral hepatic cells, central veins and portal blood vessel and bile ducts (Fig. 5-a). Mild to moderate congestion of blood vessels, hyperplasia of bile ducts and vacuolar degeneration of hepatocytes were observed after 5 weeks of profenofos exposure (Fig. 5-b). The chronic administration (10 weeks exposure) induced severe changes that include severe hyperplasia of bile ducts, mild to moderate fibrosis, severe congestion and dilatations of blood vessel and focal areas of hepatitis represented by aggregates of lymphocytes and few macrophages (Figs. 5-C). Focal areas of hemorrhages, edema and necrosis of hepatocytes were also observed (Fig. 5-d). In contrast, in profenofos ascorbic acid treated group, mild degenerative change was observed in the hepatocytes surrounding the central vein, associated with congestion in the portal vein, edema and mild hyperplasia of the bile ducts in the portal area, mild fibrosis in the portal area with degeneration in surrounding hepatocytes.

In our study, all of the biochemical alteration of the redox state that were induced by profenofos exposure were almost or at least partially normalized when vitamins $\mathrm{C}$ was administered along with profenofos. Moreover treatment of profenofos-exposed rats with vitamin $C$ revised profenofos effects on sperm motility, viability, morphology, and the integrity of the testis. Profenofos treated group exhibited testicular and hepatic inflammatory histopathological deviations, these changes were less severe in the profenofos - vitamin treated group. Thus, vitamins $C$ could ameliorate the hepatic and testicular tissue damage induced by profenofos exposure. 

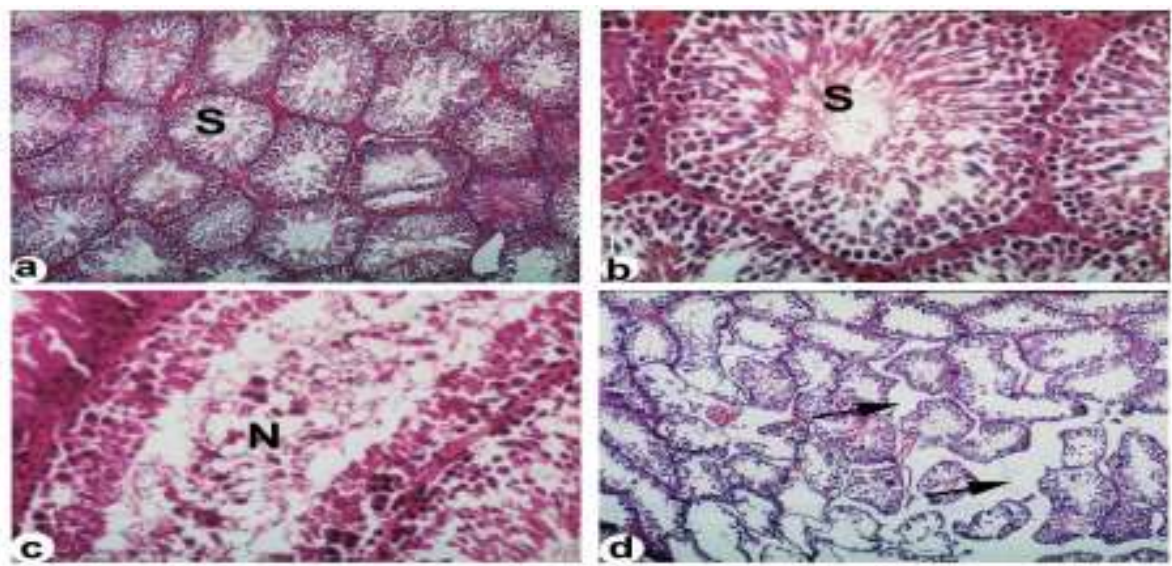

Figure 3: Testicular section stained using H\&E. (a) \& (b): Showing norma spermatogenesis and normal cell arrangement in the seminiferous tubules [S] X100 \& X400. (c): Testicular tissues of rats intoxicated with $17.4 \mathrm{mg} / \mathrm{kg}$ profenofos for 5 weeks, showing degeneration of seminiferous tubule and sloughing of germ cells into the tubular lumen [N]. X 400. (d): After 10 weeks exposure, the interstitial space showing edema (arrows), congestion of blood vessels and tubular atrophy of the semineferous tubules, and some sections had no spermatozoa.
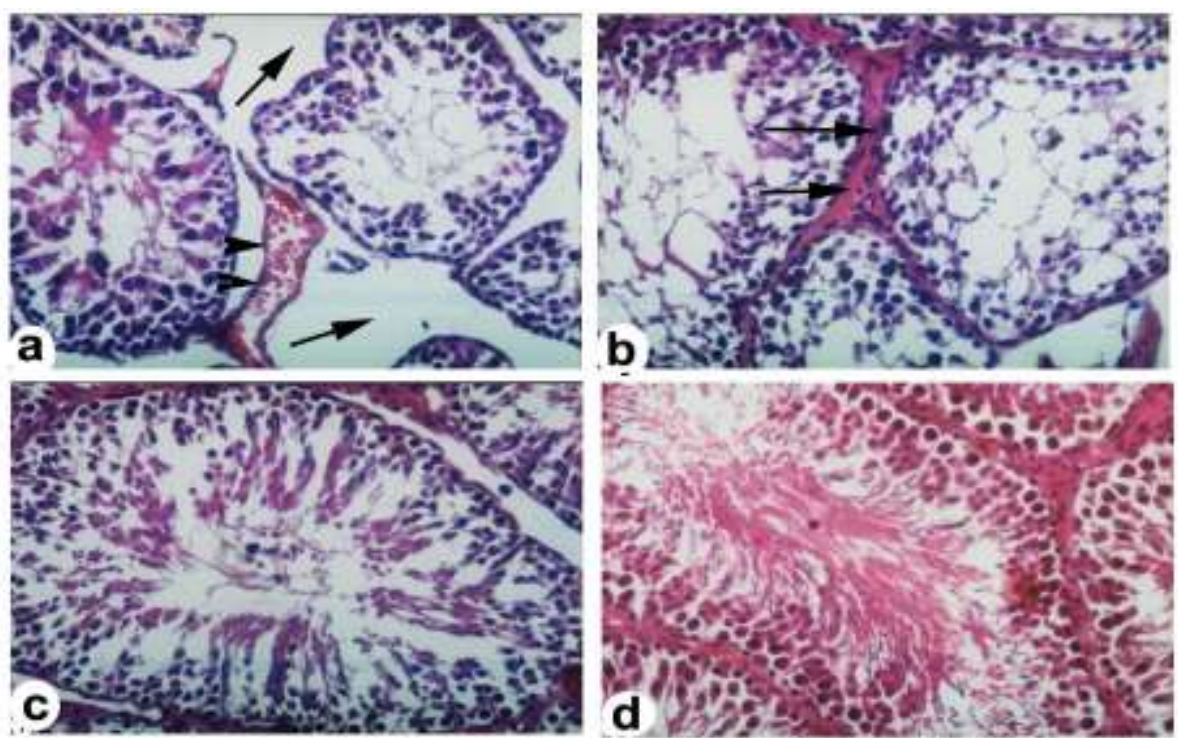

Figure 4: Testicular section stained using H\&E. (a): After 10-weeks exposure, the interstitial space showing edema (arrows), congestion of blood vessels (arrow heads). (b): semnifrous tubules showed thickening and hyalinization of basement membranes (arrows), and lined with few number of spermatogenic cells that having degeneration and necrotic changes (c): Testis of rats treated with profenofos and ascorbic acid for 5 weeks showing mild degeneration of spermatogenic cells, $X$ 400. (d): Testis after 10 weeks showing normal seminefrous tubule with fair spermatogenesis and formation of spermatozoa, $X 400$. 

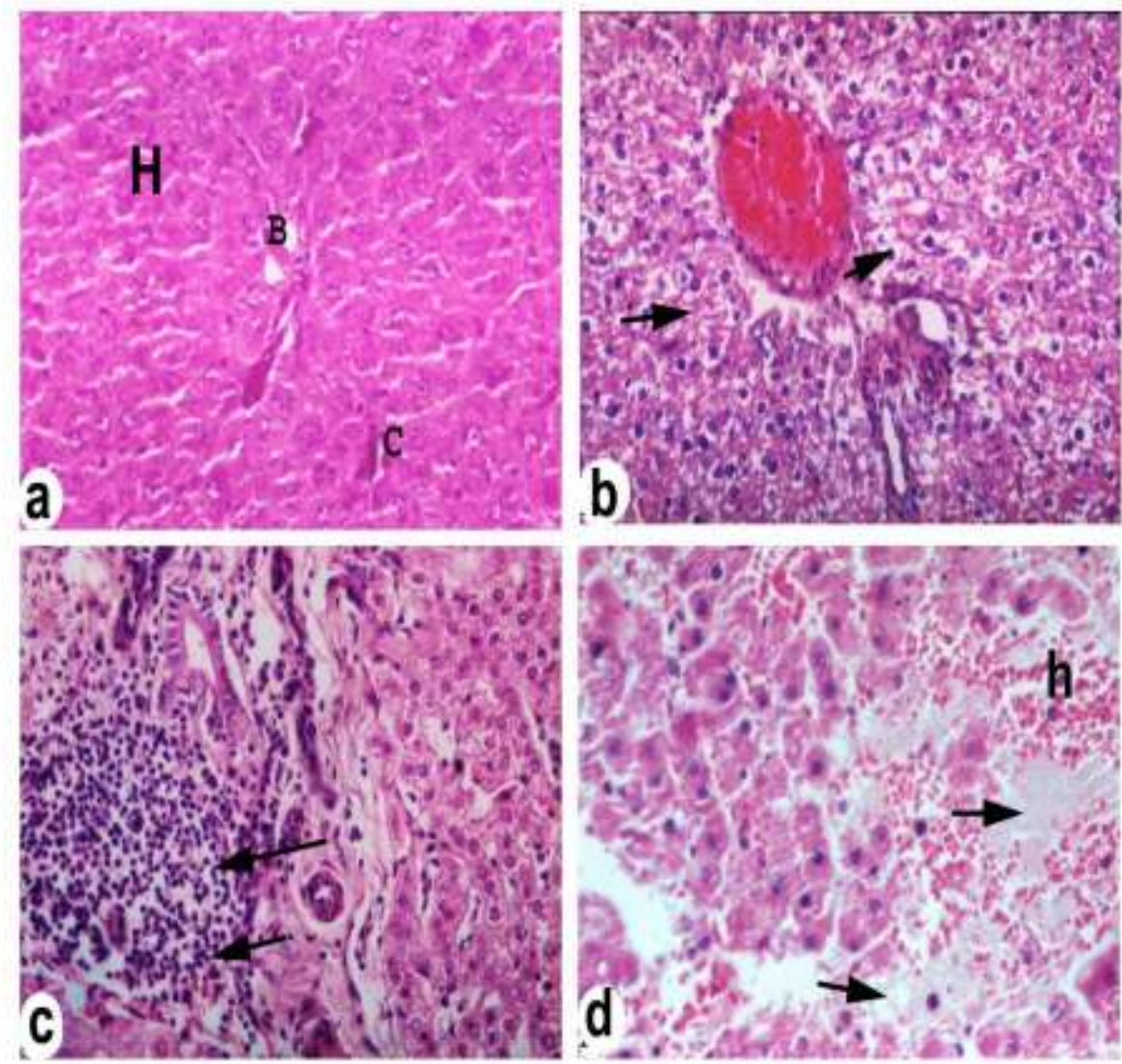

Figure 5. (a): Liver of normal rats showing normal histological appearance of hepatic cords $[\mathrm{H}]$, normal central vein and normal bile ducts in the hepatic area, $X$ 400. (b): Liver after 5 weeks of profenofos intoxication showing diffuse degeneration of hepatocytes (arrows), X 400. (c): Liver after 10 weeks of profenofos intoxication showing focal aggregates of lymphocytes and few macrophages (arrows). X 400. (d): Degeneration, edema (arrows) and necrosis of hepatocytes with hemorrhage [h] and destruction of hepatic sinusoids, $\mathrm{X} 400$.

\section{Conclusion}

The present study indicated that vitamin C provides some notable protective effect against the toxic effects of profenofos. The study clearly demonstrates the susceptibility of testicular and hepatic tissue to oxidative stress induced by profenofos, which, may be associated with serious degenerative disorders in testicular and hepatic tissues. Moreover, testosterone level decreased significantly after the exposure to profenofos. 


\section{Dessouki, Amina et al.}

The present study has also revealed that alterations in male reproductive function or fertility may occur as a result of exposure to profenofos. Since mature spermatozoa are the most probable target of oxidant injury, the impact of environmental contamination on human fertility and mutagenic effects should be investigated in greater detail. The toxicological effects reported in the present study would probably occur in human populations involuntarily exposed to organophosphate contaminated environment and food.

\section{REFERENCES}

Acharya, U.R.; Mishra, M.; Patro, J. and Panda, M.K. (2008): Effect of vitamins $\mathrm{C}$ and Eon spermatogenesis in mice exposed to cadmium Reprod., Toxicol., 22 : 87-91.

Aebi, H. (1974). Catalase. In : Bergmeyer, HU (ed.), Methods of Enzymatic Analysis. Academic Press Inc, Verlag, NY, 2 : 673-685.

Altuntas, I.N., Deliba,Demirci M., Kilinc I.,Tamer N. (2002). The effects of methidathion on lipid peroxidation and some liver enzymes: Role of Vitamins $\mathrm{E}$ and C. Arch Toxicol. 76:470-473.

Anderson M. E. (1985). Determination of glutathione and glutathione disulphide in biological samples.,Method. Enzymol., 113:548-551.

Astiz M, de Alaniz MJ and Carlos Alberto M (2009a). Antioxidant defense system in rats simultaneously intoxicated with agrochemicals. Environmental Toxicology and Pharmacology 28, 465-473.

Astiz M, de Alaniz MJ and Carlos Alberto M. (2009b).The impact of simultaneous intoxication with agrochemicals on the antioxidant defense system in rat. Pesticide Biochemistry and Physiology 94, 9399.

Beuret, C.J., Zirulnik, F., Gimenez, M.S. (2005). Effect of the herbicide glyphosate on liver lipoperoxidation in pregnant rats and their fetuses. Reprod. Toxicol. 19, 501-504.

Buettner, GR. (1993). The pecking order of free radicals and antioxidants: lipid peroxidation, a-tocopherol, and ascorbate. Arch. Biochem. Biophys. 300: 535-543.

Bustin S.A., Benes V. Nolan T. and Pfaffl M.W. (2005). Quantitative real-time RT-PCR-a perspective.Journal of Molecular Endocrinology, 34:597601.

Buyukokuroğlu, M. E., Cemek, M., Tosun, M., Yurumez, Y., Bas, O., Yavuz, Y. (2008). Dantrolene may prevent organophosphate-induced oxidative stress and muscle injury. Pestic. Biochem. Phys. 92, 156-163.

Cadenas, E. and Packer, L. (2002). Handbook of Antioxidants, second ed., Marcel Dekker, New York, pp. 99-108.

De Zwart, LL. Meerman, JH. Commandeur, JNM. Vermeulen, NPE. (1999). Biomarkers of free radical damage applications in experimental animals and in humans, Free Radic. Biol. Med. 26 , 202-226.

Dringen R (2005). Oxidative and antioxidative potential of brain microglial cells. Antioxid. Redox Signal. 7, 1223-1233. 
Fatma Gokce Uzun, Suna Kalender, Dilek Durak, Filiz Demir, Yusuf Kalender (2009). Malathion-induced hepatotoxicity in rats: The effects of vitamins C and E. Food and Chemical Toxicology, 47 (8), 1903-1908.

Ferah Sayım (2007). Effects of Dimethoate on testis of rats. Bull Environ Contam Toxicol. 78:479-484.

Forejt, J. (1976). Spermatogenic failure of translocation heterozygotes affected by $\mathrm{H}-2$ inbreed gene in mouse. Nature 260, 143-145.

Gangadharan, B.; Murugan, M. A. and Mathur, P.P. (2001): Effect of methoxychlor on antioxidant system of goat epididymal sperm in vitro. Asian J. Androl., 3: 285-288.

Halliwell, B. and Gutteridge, JMC. (1999). Free Radicals in Biology and Medicine, third edition. Oxford Science Publications.

Jurczuk, M., Brzoska, M.M., Moniuszko-Jakoniuk, J., (2007). Hepatic and renal concentrations of vitamins $E$ and $C$ in lead- and ethanol-exposed rats. An assessment of their involvement in the mechanisms of peroxidative damage. Food Chem. Toxicol. 45, 1478-1486.

Kalender, S., Gokce Uzun, F., Durak, D., Demir, F. and Kalender, Y. (2010). Malathion-induced hepatotoxicity in rats: The effects of vitamins $C$ and E. Food and Chemical Toxicology 48, 633-638.

Krazanowska H (1976). Inheritance of sperm head abnormalities types in mice and the role of Y-chromosomes. Genet. Res. 28, 189-198.

Latchoumycandane, C., Chitra, K.C., Mathur, P.P. (2002). The effect of methoxychlor on the epididymal antioxidant system of adult rats. Reprod. Toxicol. 16, 161-172.

Misera, H. P. and Fridovich (1972). Therole of superoxide anion in the autooxidation of epinephrine and a simple assay for superoxide dismutase. J. Biol. Chem. 247, 3170.

Moustafa, G.G.; Ibrahim, Z.S.; Hashimoto, Y.; Alkelch, A. M.; Sakamoto, K. Q.; Ishizuka, M. and Fujita, S. (2007). Testicular toxicity of profenofos in matured male rats. Arch. Toxicol., 81: 875-881.

Ohkawa, H.; Ohishi, N. and Yagi, N. (1979). Assay for Lipid peroxides in animal tissues by thiobarbituric acid reaction. Ann Biochem, 5: 351-58.

Orita, M., Iwahana, H., Kanazawa, H., Hayashi, K. and Sekiya, T. (1989). Detection of polymorphisms of human DNA by gel electrophoresis as single-strand conformation polymorphisms. Proc. Natl. Acad. Sci. USA 86, 2766-2770.

Patel S, Singh V., Kumar A., Gupta YK., Singh, MP. (2006). Status of antioxidant defense system and expression of toxicant responsive genes in striatum of maneb- and paraquat-induced Parkinson's disease phenotype in mouse: mechanism of neurodegeneration. Brain Res. 1081, 9-18.

Prahalathan C, Selvakumar E and Varalakshmi P (2006). Modulatory role of lipoic acid on andriamycin-induced testicular injury. Chem. Biol. Interact. 160: 108-114.

Prakasam A, Sethupathy S, Lalitha S. (2001). Plasma and RBCs antioxidant status in occupational male pesticide sprayers. Clin Chem Acta 310:107-12. 
Rai DK, Rai P., Rizvi SI, Watal G, Sharma B. (2009). Carbofuran-induced toxicity in rats: Protective role of vitamin C. Experimental and Toxicologic Pathology 61 531-535.

Sarabia, L., Maurer, I., Bustos-Obregn, E. (2009). Melatonin prevents damage elicited by the organophosphorous pesticide diazinon on mouse sperm DNA. Exotoxicol. Environ. Saf. 72, 663-668.

Saradha, B. and Mathur, PP. (2006): Effect of environmental contaminants on male reproduction. Environ. Toxicol. Pharmacol. 21: 34-41.

SAS Program (1994). SAS User Guide Statistics. SAS Inst. Carry, NC., USA.

Serbecic, N. and Beutelspacher, SC. (2005): Anti-oxidative vitamins prevent lipidperoxidation and apoptosis in corneal endothelial cells. Cell. Tissue Res. 320, 465-475.

Sharma, Y., Bashir, S., Irshad, M, Nag, TC., and Dogra, TD. (2005): Dimethoate-induced effects on antioxidant status of liver and brain of rats following subchronic exposure. Toxicology, 215: 173-181.

Sheffield, V. C., Beck, J. S., Kwitek, A. E., Sandstrom, D. W. and Stone, E. M. (1993). The sensitivity of single-strand conformation polymorphism analysis for the detection of single base substitutions. Genomics 16, $325-332$.

Sikka, S.C., Rajasekaran M., and Hellstrom W.J. (1995). Role of oxidative stress and antioxidants in male infertility, J. Androl. 16, 464-468.

Sonmez M. Turk G. and Yuice, A. (2005). The effect of ascorbic acid supplementation on sperm quality lipid peroxiadtion and testosterone levels in male wistar rats. The riogenology 63 (7), 2063-2072.

Sultatos, L.G.(1994). Mammalian toxicity of organophosphorus pestiside. J. Toxicol. Environ. Health 43, 271-289.

Uzun, F.G., Kalender, S., Durak, D., Demir, F., Kalender, Y. (2009). Malathion-induced testicular toxicity in male rats and the protective effect of vitamins $C$ and E. Food Chem. Toxicol. 47, 1903-1908.

Uzunhisarcikli, M., Kalender, Y., Dirican, K., Kalender, S., Ogutcu, A., Buyukkomurcu, F. (2007). Acute, subacute and subchronic administration of methyl parathion-induced testicular damage in male rats and protective role of vitamins $\mathrm{C}$ and E. Pestic. Biochem. Phys. 87, 115-122.

Verma, R.S., Mehta, A., Srivastava, N. (2007). In vivo chlorpyrifos induced oxidative stress: attenuation by antioxidant vitamins. Pestic. Biochem. Phys. 88, 191-196. 
التحولات التي تطرا علي جين P53 ، وانسجة الخصية والكبد في الفئران الالبينو

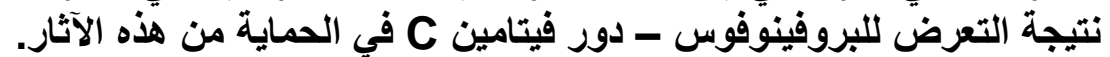

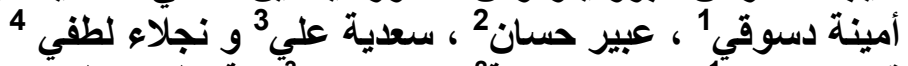

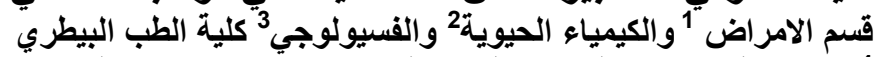

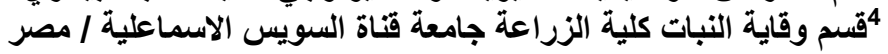

Cم تقييم أثار برفينوفوس في خصية الكبد و الخصية للفئر ان منفردا اومختلطا مع فيتامين

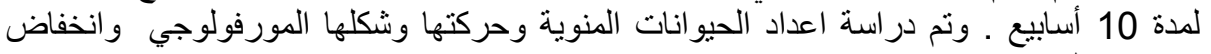
مستوي كل من malodialdehyde، dismutase، superoxide, glutathione - testosterone ـ ـ لوحظ انخفاض معنوي في حيوية وحركة الحيو انات المنوية الانية في الفئران المعاملة.

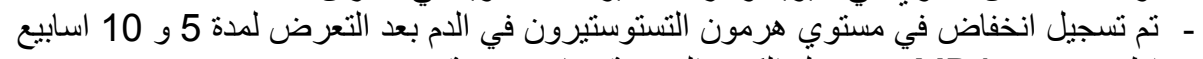

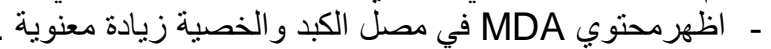

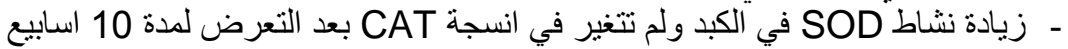

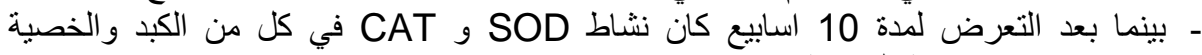
منخفضا عن مجمو عة المقارنة. - مع نهاية فترني التعرض كانت مستويات GSA في كلا نوعي الانسجة تحت الدراسة عاليات

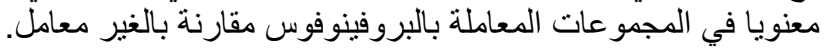

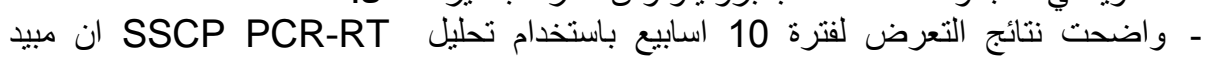
البروفينوفوس إحداث سمية جينية.

كلية الزراعة - جامعة المنصورة

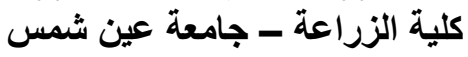

\author{
قام بتحكيم البحث

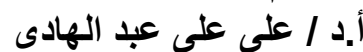 \\ أ.د / أل / محمد ابراهيم عبد المجيد
}


Dessouki, Amina et al. 
J. Plant Prot. and Path., Mansoura Univ., Vol. 3 (5), May, 2012 
J. Plant Prot. and Path., Mansoura Univ., Vol. 3 (5): 415 - 433, 2012

Table (1): Effect of profenofos andlor ascorbic acid treatment on epididymal semen picture of rats

\begin{tabular}{|c|c|c|c|c|c|c|c|c|c|c|}
\hline \multirow{3}{*}{ Treatment } & \multicolumn{5}{|c|}{ Five weeks treatment } & \multicolumn{5}{|c|}{ Ten weeks treatment } \\
\hline & \multirow{2}{*}{\begin{tabular}{|l} 
Individual \\
motility \%
\end{tabular}} & \multirow{2}{*}{$\%$ Live } & \multicolumn{3}{|c|}{ Sperm abnormalities \% } & \multirow{2}{*}{$\begin{array}{l}\text { Individual } \\
\text { motility \% }\end{array}$} & \multirow{2}{*}{$\%$ Live } & \multicolumn{3}{|c|}{ Sperm abnormalities \% } \\
\hline & & & Primary & Secondary & Total & & & \begin{tabular}{|l} 
Primary \\
\end{tabular} & Secondary & Total \\
\hline \multirow[t]{2}{*}{ Control } & $72.21^{b}$ & $85.73^{\mathrm{a}}$ & $3.59^{b}$ & $9.01^{b}$ & $12.60^{b}$ & $73.52^{b}$ & $84.71^{\mathrm{a}}$ & $3.47^{b}$ & $8.97^{b}$ & $12.44^{b}$ \\
\hline & \pm 0.54 & \pm 0.81 & \pm 0.13 & \pm 0.31 & \pm 0.25 & \pm 0.41 & \pm 0.92 & \pm 0.16 & \pm 0.22 & \pm 0.28 \\
\hline \multirow[t]{2}{*}{ Profenofos } & $58.61^{A C}$ & $51.79^{C}$ & $10.12^{\mathrm{Ba}} \pm$ & $19.14^{\mathrm{a}}$ & $29.26^{\mathrm{Ba}}$ & $43.60^{\mathrm{Bd}} \pm 0.33$ & $49.65^{c}$ & $16.52^{\mathrm{Aa}}$ & $22.13^{a}$ & $38.65^{\text {Aa }}$ \\
\hline & \pm 0.32 & \pm 0.52 & 0.45 & \pm 0.43 & \pm 0.91 & & \pm 0.43 & \pm 0.95 & \pm 1.47 & \pm 2.67 \\
\hline \multirow{2}{*}{$\begin{array}{l}\text { Profenofos+ascorbic } \\
\text { acid }\end{array}$} & $61.37^{A C}$ & $58.72^{b}$ & $9.62^{\mathrm{Ba}}$ & $16.59^{a}$ & $26.22^{\mathrm{Ba}}$ & $49.52^{\mathrm{BC}}$ & $55.45^{b}$ & $15.43^{\mathrm{Aa}}$ & $19.69^{a}$ & $35.15^{\mathrm{Aa}}$ \\
\hline & \pm 0.41 & \pm 0.39 & \pm 0.31 & \pm 0.62 & \pm 0.57 & \pm 0.48 & \pm 0.25 & \pm 0.45 & \pm 0.63 & \pm 0.46 \\
\hline \multirow[t]{2}{*}{ Ascorbic acid } & $76.53^{\mathrm{a}}$ & $89.42^{a}$ & $3.22^{b}$ & $7.45^{b}$ & $10.68^{\mathrm{C}}$ & $78.69^{a}$ & $90.11^{a}$ & $3.55^{b}$ & $7.63^{b}$ & $11.17^{b}$ \\
\hline & \pm 0.36 & \pm 0.71 & \pm 0.12 & \pm 0.45 & \pm 0.12 & \pm 0.57 & \pm 0.82 & \pm 0.23 & \pm 0.31 & \pm 0.53 \\
\hline
\end{tabular}

Values are expressed as Mean \pm SE.

| Values having different small letters in the same column differ significantly at $P<0.05$.

In comparing similar parameters between 5 and 10 weeks treatment, values having different capital letters in the same row differ | significantly at $\mathbf{P}<0.05$, 
Table (3): Effect of Profenofos and/or ascorbic acid on catalase (CAT), glutathione (GSH) and super-oxide dismutase (SOD) activities in rats

\begin{tabular}{|c|c|c|c|c|c|c|c|c|c|c|c|c|}
\hline \multirow{3}{*}{ Treatment } & \multicolumn{4}{|c|}{ Catalase (CAT) (U/g) } & \multicolumn{4}{|c|}{ Super-oxide dismutase (SOD) (U/g) } & \multicolumn{4}{|c|}{ Glutathione (GSH) (mg/g) } \\
\hline & \multicolumn{2}{|c|}{ Testis } & \multicolumn{2}{|c|}{ Hepatic } & \multicolumn{2}{|c|}{ Testis } & \multicolumn{2}{|c|}{ Hepatic } & \multicolumn{2}{|c|}{ Testis } & \multicolumn{2}{|c|}{ Hepatic } \\
\hline & 5 weeks & $\begin{array}{c}10 \\
\text { weeks }\end{array}$ & 5 weeks & 10 weeks & 5 weeks & $\begin{array}{c}10 \\
\text { weeks }\end{array}$ & 5 weeks & $\begin{array}{c}10 \\
\text { weeks }\end{array}$ & 5 weeks & $\begin{array}{c}10 \\
\text { weeks }\end{array}$ & 5 weeks & $\begin{array}{c}10 \\
\text { weeks }\end{array}$ \\
\hline Control & $\begin{array}{l}756.5^{ \pm} \\
13.5^{\mathrm{b}}\end{array}$ & $\begin{array}{l}696.6 \pm \\
11.4^{\mathrm{a}}\end{array}$ & $\begin{array}{c}719.04 \pm \\
15.1^{\mathrm{b}}\end{array}$ & $\begin{array}{c}789.04 \pm \\
18.1^{\mathrm{b}}\end{array}$ & $\begin{array}{c}360.06 \pm 1 \\
5.3^{a}\end{array}$ & $\begin{array}{c}330.00 \pm 1 \\
5.5^{\mathrm{a}}\end{array}$ & $\begin{array}{l}38.99 \pm 1 \\
2.9^{\mathrm{bc}}\end{array}$ & $\begin{array}{c}360.59 \pm 1 \\
3.3^{b}\end{array}$ & $\begin{array}{l}2.17 \pm \\
0.31^{c}\end{array}$ & $\begin{array}{l}1.98 \pm \\
0.34^{c}\end{array}$ & $\begin{array}{l}1.90 \pm \\
0.14^{\mathrm{C}}\end{array}$ & $\begin{array}{l}2.59 \pm \\
0.36^{\mathrm{c}}\end{array}$ \\
\hline Profenofos & $\begin{array}{c}581.79 \pm \\
15.9^{c}\end{array}$ & $\begin{array}{l}554.5^{ \pm} \\
21.4^{\mathrm{b}}\end{array}$ & $\begin{array}{c}614.08 \pm \\
17.7^{\text {cd }}\end{array}$ & $\begin{array}{c}574.00 \pm \\
11.2^{\mathrm{C}}\end{array}$ & $\begin{array}{c}306.18 \pm 1 \\
6.2^{\mathrm{b}}\end{array}$ & $\begin{array}{c}227.06 \pm 1 \\
1.2^{b}\end{array}$ & $\begin{array}{c}379.96 \pm 1 \\
2.7^{a}\end{array}$ & $\begin{array}{c}321.95 \pm 1 \\
1.8^{c}\end{array}$ & $\begin{array}{l}5.09 \pm \\
0.31^{a}\end{array}$ & $\begin{array}{l}5.27 \pm t \\
0.14^{b}\end{array}$ & $\begin{array}{l}5.42 \pm \\
0.13^{b}\end{array}$ & $\begin{array}{l}4.99 \pm \\
0.21^{\mathrm{b}}\end{array}$ \\
\hline $\begin{array}{l}\text { Profenofos+ } \\
\text { ascorbic acid }\end{array}$ & $\begin{array}{c}692.59 \pm \\
13.8^{b}\end{array}$ & $\begin{array}{c}672.95 \pm \\
16.96^{\mathrm{a}}\end{array}$ & $\begin{array}{c}557.03 \pm \\
14.2^{d}\end{array}$ & $\begin{array}{c}621.01 \pm \\
13.9^{c}\end{array}$ & $\begin{array}{c}331.10 \pm 1 \\
1.0^{\mathrm{ab}}\end{array}$ & $\begin{array}{c}266.96 \pm 1 \\
6.3^{b}\end{array}$ & $\begin{array}{c}331.94 \pm 1 \\
6.2^{\mathrm{c}}\end{array}$ & $\begin{array}{c}326.98 \pm 1 \\
5.3^{c}\end{array}$ & $\begin{array}{l}3.94 \pm \frac{ \pm}{b} \\
0.27^{b}\end{array}$ & $\begin{array}{l}2.59 \pm \\
0.39^{c}\end{array}$ & $\begin{array}{l}6.81 \pm \\
0.76^{b}\end{array}$ & $\begin{array}{l}5.79 \pm \\
0.28^{\mathrm{b}}\end{array}$ \\
\hline Ascorbic acid & $\begin{array}{c}837.79 \pm \\
12.7^{\mathrm{Aa}}\end{array}$ & $\begin{array}{l}712.02 \pm \\
22.63^{\mathrm{Ba}}\end{array}$ & $\begin{array}{c}1263.01 \pm 1 \\
4.3^{\mathrm{Aa}}\end{array}$ & $\begin{array}{c}1137.06 \pm 1 \\
8.9^{\mathrm{Ba}}\end{array}$ & $\begin{array}{c}332.05 \pm 1 \\
3.9^{\mathrm{ab}}\end{array}$ & $\begin{array}{c}321.00 \pm 1 \\
5.3^{\mathrm{a}}\end{array}$ & $\begin{array}{c}355.94 \pm 1 \\
5.7^{\mathrm{b}}\end{array}$ & $\begin{array}{c}408.14 \pm 1 \\
2.3^{a}\end{array}$ & $\begin{array}{l}6.10 \pm \\
0.34^{\mathrm{Ba}}\end{array}$ & $\begin{array}{c}8.50 \pm \\
0.53^{\mathrm{Aa}}\end{array}$ & $\begin{array}{l}11.97 \pm \\
0.42^{\mathrm{Ba}}\end{array}$ & $\begin{array}{l}17.52 \pm \\
0.44^{\mathrm{Aa}}\end{array}$ \\
\hline
\end{tabular}

Values are expressed as Mean $\pm \mathrm{SE}$.

Values having different small letters in the same column differ significantly at $\mathrm{P}<0.05$.

In comparing similar parameters between 5 and 10 weeks treatment, values having different capital letters in the same row differ significantly at $P<0.05$. 
Table (2): Effect of profenfos and /or ascorbic acid on serum testosterone and MDa levels in different tissues in rats

\begin{tabular}{|c|c|c|c|c|c|c|c|c|}
\hline \multirow{3}{*}{ Treatment } & \multirow{2}{*}{\multicolumn{2}{|c|}{$\begin{array}{c}\text { Serum total } \\
\text { testosterone }(\mathrm{ng} / \mathrm{ml})\end{array}$}} & \multicolumn{6}{|c|}{ Malondialdehyde (MDA) } \\
\hline & & & \multicolumn{2}{|c|}{ Serum $(\mathrm{nmol} / \mathrm{ml})$} & \multicolumn{2}{|c|}{ Testis (nmol / ml) } & \multicolumn{2}{|c|}{$\begin{array}{c}\text { Liver } \\
(\mathrm{nmol} / \mathrm{ml})\end{array}$} \\
\hline & \begin{tabular}{|l|} 
Five weeks \\
\end{tabular} & Ten weeks & Five weeks & Ten weeks & Five weeks & Ten weeks & Five weeks & Ten weeks \\
\hline Control & $3.20 \pm 0.27 a$ & $3.5 \pm 0.08 \mathrm{a}$ & $8.05 \pm 0.03 b$ & $7.53 \pm 0.13 b$ & $10.59 \pm 0.25 b$ & $11.6 \pm 0.17 \mathrm{bc}$ & $15.1 \pm 0.98 c$ & $16.7 \pm 0.6 \mathrm{~b}$ \\
\hline Profenofos & $0.82 \pm 0.06 \mathrm{ab}$ & $0.57 \pm 0.01 b c$ & $9.80 \pm 0.09 a b$ & $16.92 \pm 0.5 \mathrm{ba}$ & $19.45 \pm 0.12 a$ & $21.1 \pm 1.40 \mathrm{a}$ & $21.3 \pm 0.29 a b$ & $29.5 \pm 1.2 \mathrm{aa}$ \\
\hline $\begin{array}{l}\text { Profenofos+ascorbic } \\
\text { acid }\end{array}$ & ${ }^{1.10} \pm 0.03 \mathrm{~b}$ & $1.19 \pm 0.07 b$ & $7.91 \pm 0.08 b$ & $7.25 \pm 0.06 \mathrm{~b}$ & $11.25 \pm 0.25 b$ & $12.7 \pm 0.4 \mathrm{~b}$ & $18.5 \pm 0.65 \mathrm{bb}$ & $26.5 \pm 0.14 \mathrm{Aa}$ \\
\hline Ascorbic acid & $3.65 \pm 0.01 a$ & $4.03 \pm 0.18$ & $2.93 \pm 0.05 b c$ & $5.09 \pm 0.05 a b$ & $8.15 \pm 0.30 c$ & $9.25 \pm 0.05$ & $7.4 \pm 0.02 \mathrm{bd}$ & $9.3 \pm 1.03 \mathrm{Ab}$ \\
\hline
\end{tabular}

Values are expressed as Mean $\pm \mathrm{SE}$.

Values having different small letters in the same column differ significantly at $P<0.05$.

In comparing similar parameters between 5 and 10 weeks treatment, values having different capital letters in the same row differ significantly at $P<0.05$. 
J. Plant Prot. and Path., Mansoura Univ., Vol. 3 (5), May, 2012 